\title{
Problems of genesis, evolution and protection of the Una tuff in Una National Park
}

\author{
Muriz Spahić, Aida Korjenic \& Edin Hrelja
}

Keywords: tuff, genesis, evolution, tuff age, indication factor, physical-geographic conditions, thalweg, cascades, dams, overflows, waterfalls

\section{Abstract}

Tuff gives the Una River its distinct type of flow, unique in the world. In the clear blue water of the Una River, tuff has formed many dams with overflows and waterfalls. Its universality and uniqueness was recognized by a Roman legionary who was so overwhelmed when he reached the river that he said Una, meaning one and only in Latin. Tuff waterfalls on the Una were a decisive and indicatory factor in the 2008 assignation of the upper basin of the Una as a national park of Bosnia and Herzegovina. This article discusses the genesis and evolution of tuff cascades occurring in physicalgeographic conditions determined by specific elements, the most important of which are the carbonate geological base, water temperature, $\mathrm{pH}$ value, water clarity, presence of tuff forming plants in the river water, etc.. Because of that, all physical-geographic conditions in the Una basin must have a strict natural development regime with strict protection measures for the individual elements and the total complex.
Profile

Protected area

Una National Park

Country

Bosnia and Herzegovina

\section{Introduction}

The Una River, which forms the border with the Republic of Croatia along some of its length, abounds with tuff products. Originating in water, tuff is calcium-carbonated sediment and many rivers are famous for it, in Bosnia and Herzegovina for instance the Una, Trebižat and Pliva; in the neighbouring Republic of Croatia the Korana, Krka and Zrmanja rivers. Tuffs in the Una River and potamological studies were the subject of numerous scientific researches. The Una River is not only interesting for its tuff cascades, but also for a study of tuff cascades development (Ballif 1899) and palaeographic reconstruction of the potamological system of the Una. The process of tuff sedimentation in the Una and Korana is helped by biological processes (Srdoč et al. 1985) and by extraction of carbon dioxide from calcium hydrocarbonate solutions through mechanical processes (Gams 1969; Kanaet 1968; Horvatinčić 2000; Spahić 2000). Genesis and evolution of tuff sediments in tuff-lined rivers is closely linked with the self-development of balanced physical-geographic processes, especially geological, potamological, geomorphological and hydrobiological ones. An absolute age of tuff in the Una River has been determined by the radioactive isotope $14 \mathrm{C}$ method and by radioactive isotopes ${ }^{230} \mathrm{Th}$ and ${ }^{234} \mathrm{U}$. The first method, ${ }^{14} \mathrm{C}$, determines the maximum age up to 40000 years, and isotopes ${ }^{230} \mathrm{Th}$ and ${ }^{234} \mathrm{U}$ up to 400000 years (Horvatinčić 2000).

On the basis of the determination of absolute age and successive changes in the Una River's thalweg, a palaeographic reconstruction of tuff deposit development was carried out. The research shows that tuff in the Una basin has accumulated under the strictly regular natural-geographic conditions and will be eroded if natural geographic balance is violated. Accumulation and erosion of tuff follow a regular natural geographic rhythm which can be disturbed by anthropogenic conditions. For the Una River, tuff is a very important natural indicator phenomenon, which has been decisive for defining the Una upper basin with its influent Unac within the framework of the Una National Park (UNP). The UNP is situated at the far west, northwestern part of Bosnia and Herzegovina:

- The most northerly point: $44^{\circ} 44^{\prime} 33^{\prime \prime} \mathrm{N}$, $15^{\circ} 57^{\prime} 58^{\prime \prime} \mathrm{E}$ (Podastrana settlement);

- The most southerly point: $44^{\circ} 21^{\prime} 02^{\prime \prime} \mathrm{N}$, $16^{\circ} 13^{\prime} 05^{\prime}$ E (Gradina peak, $676 \mathrm{~m}$ );

- The most westerly point: $44^{\circ} 43^{\prime} 46^{\prime \prime} \mathrm{N}$; $15^{\circ} 54^{\prime} 12^{\prime \prime} \mathrm{E}$ (trigonometric point $509 \mathrm{~m}$ );

- The most easterly point: $44^{\circ} 23^{\prime} 46^{\prime \prime} \mathrm{N}$; $16^{\circ} 20^{\prime} 42^{\prime \prime} \mathrm{E}$ (Vrtočke Bare area).

\section{Study area}

\section{The Una and its basin}

With its basin the Una drains waters from the border region with the Republic of Croatia in the western and northwestern part of Bosnia and Herzegovina (Figure 1). The water system of the Una drains waters from an area which, by watersheds, includes territory between the basins of the Kupa and Sava in the north, the Korana in the northwest, the Zrmanja and Krka in the south and southwest, the Vrbas in the east and smaller Sava's tributaries in the northeast.

The Una River rises from a strong karst fissured source at Donja Suvaja $(375.85 \mathrm{~m})$ on the eastern slopes of Čemernica and empties into the Sava at Jasenovac $(95 \mathrm{~m})$. Its river system in general is made up of the right-hand tributaries, the longest of which are the Sana and Unac. Beside the surface flows, especially 


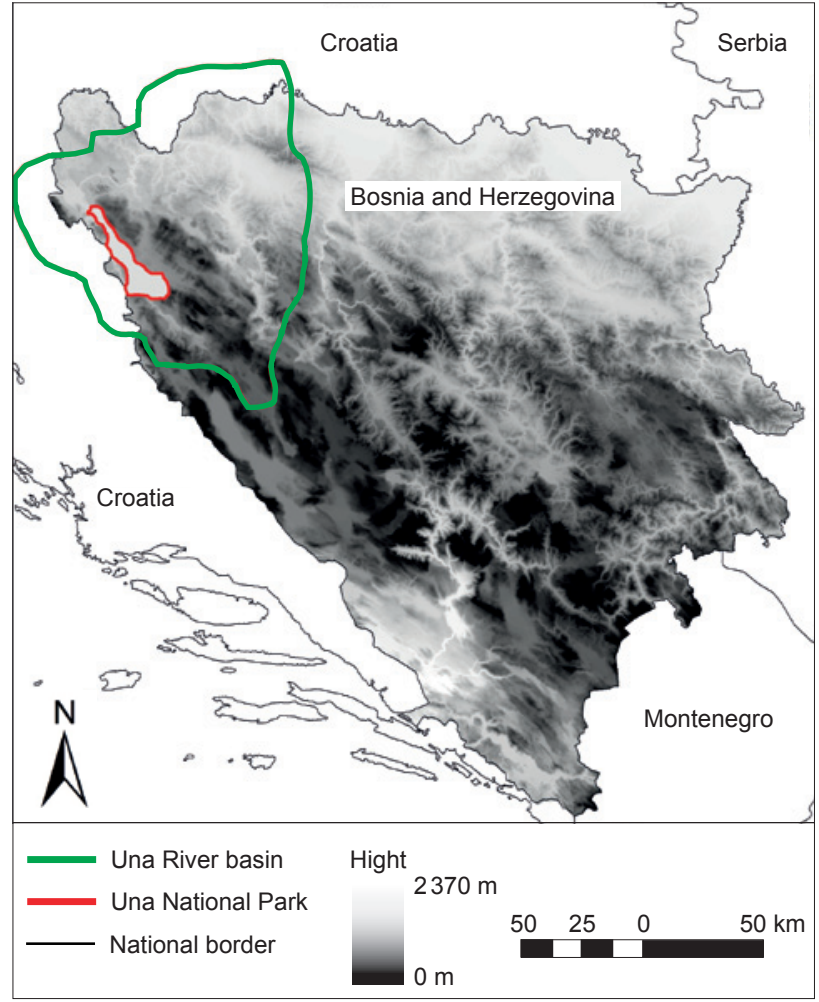

Figure 1 - Position of the Una River basin in Bosnia and Herzegovina. Database (C) Federal Ministry of Physical (Zoning) Planning (eds.) 2008. (C) Esri 2009

near the mouth of the Unac-Bihać, the Una is fed by numerous karst sources that appear on the bottom of the river-bed.

On the surface and underground, from the upper and middle basin, the Una drains the higher zone of high karst, and in the lower part first a zone of Mesozoic limestone and dolomites, then a central Palaeozoic and Ophiolite zone, while at the junction with the Sava, its basin is situated in the inner flysch zone. Such a morphostructural basin plan points to a very complex geological structure. The upper and middle basin form a karstificated carbonated complex, with limited surface contact and more expressed underground contact. The basin's middle part belongs to a sediment-metamorphic complex with mostly surface contact, while its terminal northern parts come into the structure of a molasa formation with limited capacity of underground contact.

This morphostructural plan in the Una hydrographic system has affected the formation of the dendroid type river's net asymmetrical character as indicated by the fact that the right part of the basin area is larger than the left basin area in the proportion $74 \%: 26 \%$.

The river system was formed in a basin where orographic watersheds towards neighbouring basins have often been transformed into underground watersheds. Watersheds are not quite clear towards the Vrbas, Krka and Zrmanja rivers, especially in the basin's upper parts where carbonate deposits dominate. On the basis of hydrogeological prospection and dying of

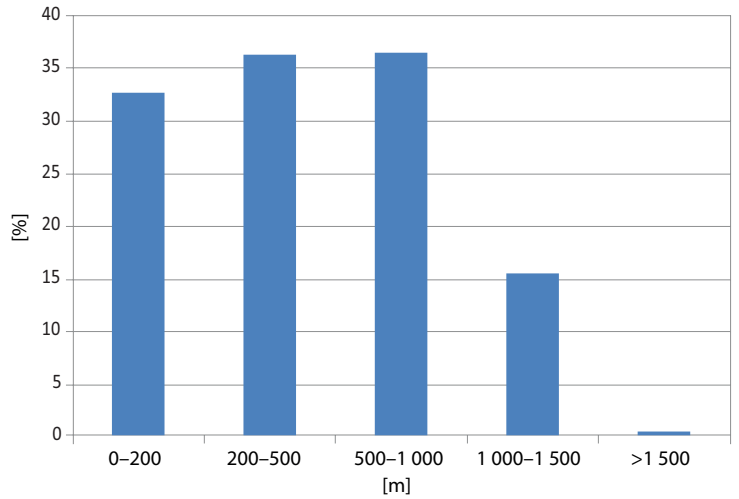

Figure 2 - Percentual share of surfaces at altitude zones in the Una basin.

groundwaters, the basin's surface area has been determined as measuring $9640 \mathrm{~km}^{2}$.

The Una basin has the characteristics of a morphologic arch which runs evenly from the Pannonian depression with very complex morphology dominated by morphostructures of fields with medium hypsometric levels of about $600 \mathrm{~m}$ (Figure 2).

The middle and southern basins form morphostructures with shapes of anticlinoria, horstanticline and arches. These are interspersed with intermountain, in mountain and premountain depressions with characteristics of sinclinorium, graben synclinals and monoclines. The greater part of the Una basin belongs to the Una-Korana plateau, which is linked to the orographic mountains of Grmeč and Plješevica. The Una-Korana plateau rose on Creatous and Trias carbonates through intensive corrosion-erosion processes, during the quiet and quite humid Pliocene.

It kept its own evolutionary development quite well in the middle flow in the Bihać - Krupa basin and the Grabež - Ostrožac plateau. These morphostructures receive precipitation waters that contribute to stable flow (Figure 3). Morphostructurally, the Una Valley represents blocked morphologic dissection with polygenetic, polyphasic and polymorphic characteristics. It consists of erosive basin extensions which are banded with rugged shrinks into the unique hydrographic system. Hypsometric series of basin and river terraces, alluvial plain coasts and fans therein point to a succession of tectonic, karst and hydroclimatic processes. Basins are filled with lacustrial lake sediments, which indicate the existence of a neogenic lake phase. They are interconnected by rugged segments, formed by the erosion of lake islands at the end of the Pliocene. Erosion processes deepened the gorges, lake levels in ravines decreased. Pliocene and post-Pliocene terraces point to successive draining of lake waters from basins. After adjustment of lake islands in gorges with the lowest lake tiers, the Una became the only channel on its whole longitudinal profile. Regressive adjustment of the Una's longitudinal profile took place towards the lower erosive base of the Pannonian basin. Processes of stagnation and draining of the Pannonian Sea corresponded to processes of resting and 
draining of waters from the basin, and to a succession of resting and cutting of islands in gorges. The Una Valley displays characteristics of recent polyphase evolution progress, testified by the growth of tuff barriers which had broken the longitudinal profile into several cuts (Figure 4).

Specific climatic influences have been at work in the Una basin, in the main as a reflection of its complex morphological constitution. The hypsometric level gradually increases from north to east, and over it air mass circulations are rotated of the southern parts of the northern moderate zone and the northern parts of the subtropical zone. Their rotation over the Una basin is modified by influences of the western inshore winter cyclone and summer Azores anticyclone, strengthened by tropical influences. The combination of the stated geographical factors creates a moderate continental type $(\mathrm{Cfb})$ climate in the Una Valley and variations of premountain (Cfbx) and mountain climates (Df) at the higher hypsometric level of the basin.

The average annual isotherm of the moderate continental climate is $10.4^{\circ} \mathrm{C}$, of the premountain climate $8-10^{\circ} \mathrm{C}$, and of the mountain climate $4-6{ }^{\circ} \mathrm{C}$, while the average annual isotherm in the Una basin is $9.4^{\circ} \mathrm{C}$. The isohyets regime has combined characteristics of the continental and changed Mediterranean influences. Because of that, two isohyet maxima occur: the first in June, as a consequence of continental influences, and the second one in December, as a consequence of maritime influences. Minimum precipitation in the basin regularly occurs in August and September. Average annual isohyets in the Una basin are $111.4 \mathrm{~mm}$. On the whole basin of the Una River, average precipitation throughout the year amounts to 12.7 million $\mathrm{m}^{3}$.

\section{Physicalgeographic characteristics of the Una River's regime}

Water meter monitoring on the Una has been carried out for some time, at several stations, but the basin's general physicalgeographic characteristics determine the analysis of characteristic regimes for the upper, middle and lower longitudinal profile. The monitoring of hydrologic stations points to periods of distinctly low water conditions from June to October and higher ones from November to May. Such a division of water conditions corresponds to the difference between continental influences during the transition from spring to summer and more extraordinary maritime influences during the colder period of year.

More significant deviations in an annual distribution of maximum water condition and flow on the Una River are conditioned by karst and nival retention. There is significant differential between maximum water and average water levels at all water meter stations. Maximum amplitudes go from $359 \mathrm{~cm}$ in the upper reaches to $488 \mathrm{~cm}$ in the middle and $456 \mathrm{~cm}$ at the outflow into the Sava (Figure 5).

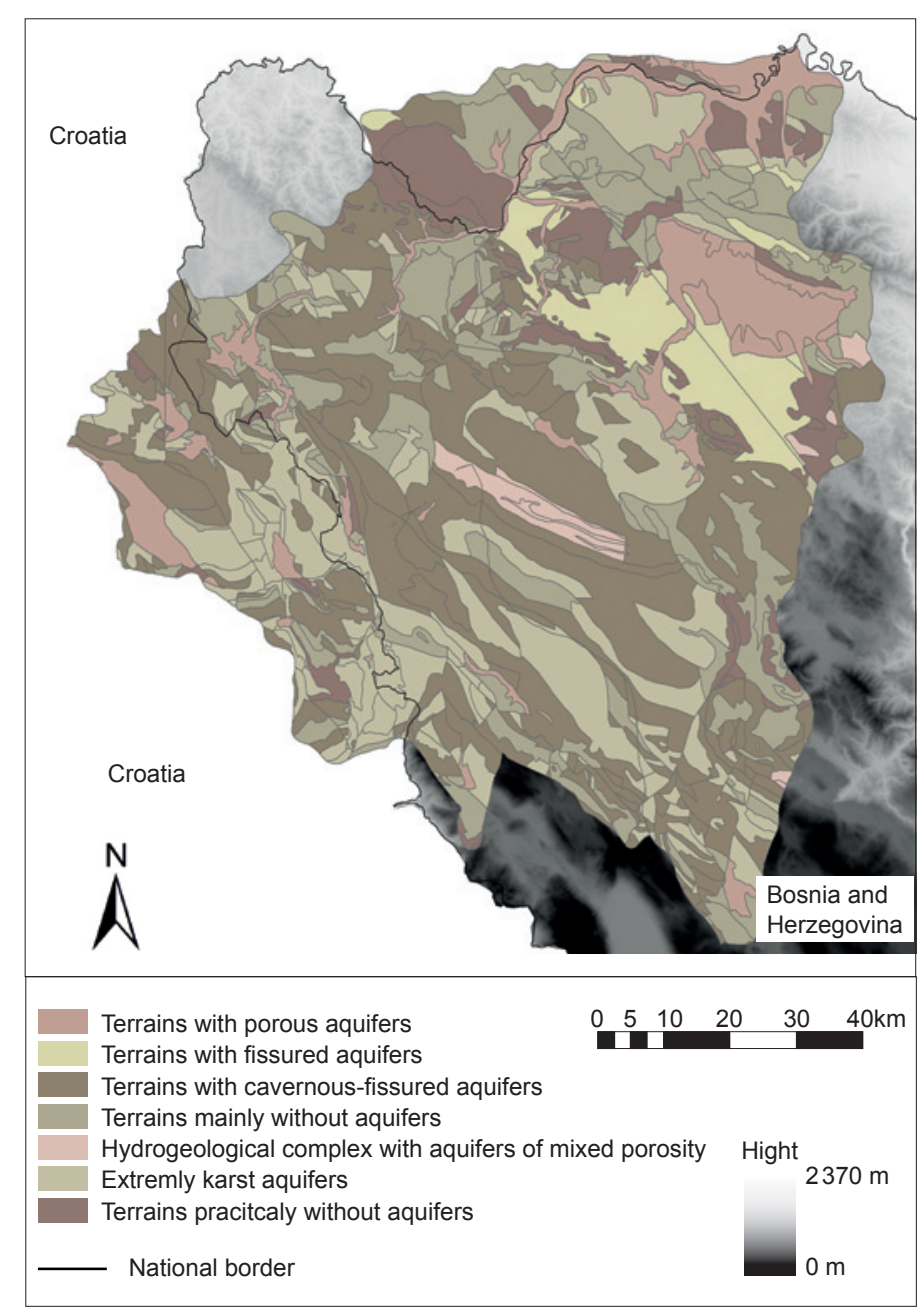

Figure 3 - Hydrogeological relations in the Una River basin. (C) Federal Ministry of Physical (Zoning) Planning (eds.) 2008. (C) Esri 2009

More favourable possibilities for detailed conclusions on the Una's regime are given by indicators on flow. At all three water meters the category of underground and stable flow has increased and amounts to $62.6 \%$, which points to the basin's karst character (Figure 6). Of the total precipitation (12.7 million $\mathrm{m}^{3}$ ) the Una brings approximately 7.9 million $\mathrm{m}^{3}$ of water per year to the Sava, while the remaining precipitation is lost to the karst underground, to evaporation and transpiration.

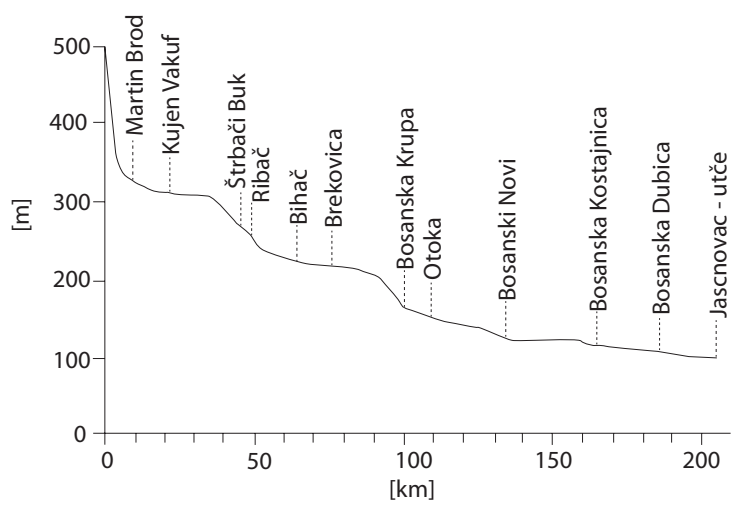

Figure 4-Longitudinal profile of the River Una. 


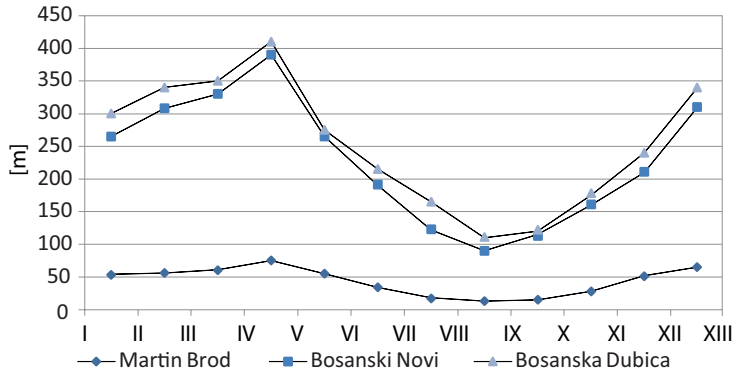

Figure 5 - The average change in flow of the River Una in the water meters in Martin Brod, Bosanski Novi and Bosanska Dubica. Author: E. Hrelja, 2014.

\section{The Una cascades}

From its source to its confluence with the Sava River, the Una displays an uneven and gradual longitudinal profile. The biggest fractures are recorded in the Una's upper source flow where falls on thalwegs amount to $0.23 \%$. On this segment, significant falls have emerged, originating in initial fractures, later on increased by tuff accumulation, such as the Martin Brod and Štrbački waterfalls.

The uneven longitudinal profile of the Una River developed as a consequence of numerous rapids in the riverbed through which the water gushes. People call the Una rapids bukovi. In this segment of the Una's longitudinal profile, slapovi appear as well, representing a succession of fractures and sections on the thalweg through which laminar and then turbulent river water flows into the foothills (pedestal), behind which bukovi or rapids appear. Cascades are in fact waterfalls, with the first ones being higher and belonging to later accumulative monomorphic tuff accumulations.

Natural waterfalls (slapovi and bukovi) in the Una's upper longitudinal profile represent unique natural value, giving the river its name Una - the one and only. Accumulation and erosion of the Una waterfalls, as is the case with other cascades on tuff rivers in Bosnia and Herzegovina, are successive and temporally limited, among other factors, by changes in natural conditions, which may also be anthropogenic.

\section{The Una tuff}

Physicalgeographic conditions of the genesis and evolution of tuff in the Una

In terms of chemical composition, tuff is calcium carbonate $\left(\mathrm{CaCO}_{3}\right)$ which is excreted from the waters in karst rivers and from karst sources. The river basins of tuff rivers mostly have a geological structure of limestones and dolomites, which dominate in the Dinaric mountain system in Bosnia and Herzegovina. Basin waters enriched with carbon dioxide $\left(\mathrm{CO}_{2}\right)$ chemically corrode the carbonate rocks, creating the solution of calcium bicarbonate:

$$
\mathrm{CaCO}_{3}+\mathrm{H}_{2} \mathrm{O}+\mathrm{CO}_{2} \rightarrow \mathrm{Ca}\left(\mathrm{HCO}_{3}\right)_{2} .
$$

This solution is carried by river water, which, under the influence of mechanical turbulence, reversibly dissolves calcium bicarbonate from which tuff originates, accumulated in the river-bed:

$$
\mathrm{Ca}\left(\mathrm{HCO}_{3}\right)_{2} \rightarrow \mathrm{CaCO}_{3} \downarrow+\mathrm{CO}_{2}+\mathrm{H}_{2} \mathrm{O} .
$$

The process of tuff deposition is accelerated by phytogenic processes in water, especially in algae and mosses which take carbon dioxide from the water. This helps with the extraction of calcium carbonate which is deposited on algae, mosses, leaves and branches. That is why these plant communities are often called tuff formers.

Over many years morphogenetic analysis of tuff deposits in the Una River was primarily directed at analysing physical geography factors and not so much biological factors. According to morphogenetic analysis in the Una, tuff waterfalls initially originated on tectonic fractures on the thalweg. The water that falls over it is aerated and tuff deposition and extraction are intensified. How strong the tuff deposits grow is influenced by the wide spread of waters in several branches over tuff masses. Typical examples of such tuff barriers are Martin Brod and Štrbački buk. Martin Brod is the largest tuff waterfall in Bosnia and Herzegovina. There, from the height of $54 \mathrm{~m}$, approximately $63 \mathrm{~m}^{3} / \mathrm{s}$ of water flow. Downstream from it in the Una ravine is its most attractive waterfall - Štrbački buk. It consists of three tuff sections, with a width of about $40 \mathrm{~m}$ and a total height of $23.5 \mathrm{~m}$.

Small tuff barriers also appear in the Una's bed and raise the bed by $0.5-1.5 \mathrm{~m}$. Morphologically they resemble small cascades, over $10 \mathrm{~m}$ in width. Their genesis is conditioned by less turbulent flow which decreases ventilation and slows tuff sedimentation. The slowdown of tuff growth on small barriers is also a consequence of lower water temperatures $\left(9.4{ }^{\circ} \mathrm{C}\right)$ which doesn't allow more intensive extraction of tuff from calcium carbonate solution. Waterfalls of this type are best developed at Ripač, Bihać, Grmuša and Bosanska Krupa. Tuff in the Una can be formed also in the underground tuff tumuluses or benches, which appear in the deepest parts of the river bed. Tuff concretions of such type are banded with the dark green algae Oocardium stratum (Matoničkin \& Pavletić 1962). These tuff products grow over time in height and width and interconnect into unique transversal tuff barrier across the river bed.

\section{Discussion}

Tuff deposits in the Una's bed correspond to places of great overflowing or convex meanders. Tuff barriers in Kostel beneath Brekavica belong to this type. The whole combination of tuff cascades originated there, once used for watermills, and later on for the purposes of hydro-power stations, which use water above these waterfalls. 
We analysed of scientific works, especially from the time of detailed potamological researches of the Una River, done by Ballif who discussed the Una tuff in his work Wasserbauten in Bosnien und der Herzegovina from 1989. This research has benchmark value, in that they indicate that in the period prior to these studies intensive accumulation of tuff had occurred in the Una bed. It had built the natural barrier behind which a flow lake originated, which was becoming a threat to Bihać, the largest town in its valley. In order to eliminate the danger and create a more even flow, the tuff cascades were blown up. After this basic research, through morphologic and potamologic scientific discussions in the works of Roglić (1952), Gams (1969), Kanaet (1968) and others, who investigated a palaeogeographic reconstruction of tuff formation, to modern research published in the proceedings of the conference The Una with and without tuff, in the year 2000, which elaborates on the absolute age of tuff, as well as from projects conducted by the first author of this work, we now know that the tuff bed of the Una River is a natural polygenetic and polyphase product. The most common causes of tuff genesis include lythologic composition, natural unevenness of the longitudinal profile, turbulence in water flow, water dispersion, changes in water conditions, width of bed, depth of water, ventilation, clearness of water, participation of chemically soluble elements in waterabove all calcium carbonate, gasses in water - especially carbon dioxide, acidity, assimilation, anthropogenic influence etc. These are known and important factors which point to the complexity and certain unsolved puzzles of genesis and evolution of tuff formations. Besides, some of the listed factors are dominant for tuff genesis in certain flows and secondary in other sections.

Studying tuff in the Una, and in other tuff rivers in Bosnia and Herzegovina, we noticed that tuff does not always appear in the same physical geographic, chemical and biological conditions. Looking for a common cause of tuff genesis, we have identified the following factors:

- Tuff flows are those flows where waters, surface or underground, are drained from limestone and dolomite lythologic layers;

- to come to extraction of tuff, river water has to include a certain amount of soluble calcium bicarbonate;

- often tuff appears in places of gradable longitudinal profiles at turbulences of water or at the point of contact with hydrologic collectors and isolators;

- the emergence of tuff is a consequence of loss of carbon dioxide from a calcium bicarbonate solution; growth of tuff sediments occurs in a clear and ventilated water;

phytobentos play an important role in tuff formation, especially cyanophyta and mosses;

- the river water must not have physical chemical fluctuations through the year;

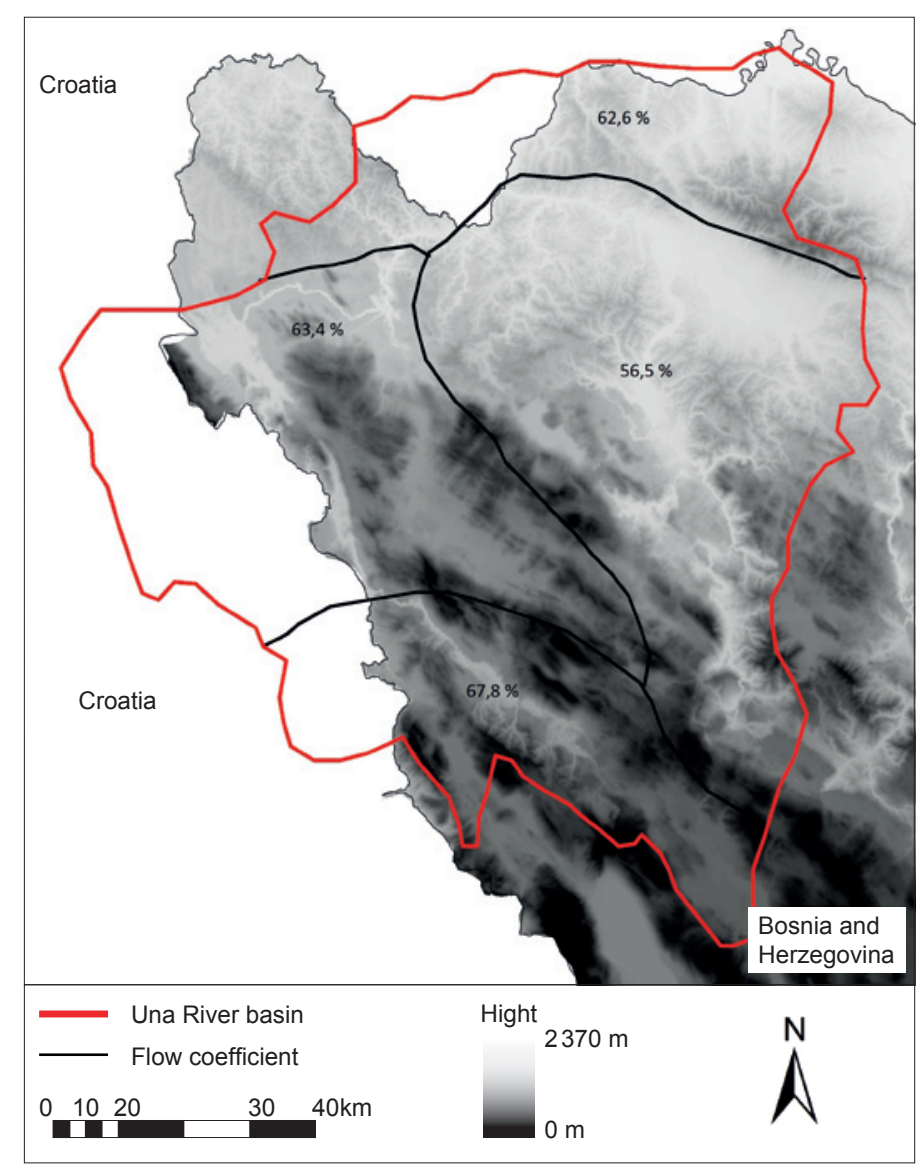

Figure 6 - The Una basin and river system divided by the value of the flow coefficient. (C) Federal Ministry of Physical (Zoning) Planning (eds.) 2008. (C) Esri 2009.

- the river regime must be stable without frequent fluctuations in water level and flow;

- the river water must be completely clear.

The role of other factors is of variable importance. On some localities and rivers they have a limited role and on others a minor or variable one. Almost all researchers emphasize the importance of water for tuff genesis. Studying tuff in the Una and Unac, Matoničkin \& Pavletić (1962) emphasized that in the upper flow of the Unac, despite it being a tuff-kind river, there is no possibility for its sedimentation because average water summer temperatures are $10{ }^{\circ} \mathrm{C}$. Other researchers stated that tuff cannot originate if average water temperatures are below $14{ }^{\circ} \mathrm{C}$. The last data are debatable because the average annual water temperature of the Una in Martin Brod has been $9.1^{\circ} \mathrm{C}$ for the last ten years and the average summer temperature for the same period $10.6{ }^{\circ} \mathrm{C}$.

There are different opinions on the role of phytobentos, which were very concisely given in the paper of Kanaet in 1968 under the title Tuff in our rivers, in which the role of plants as an active and passive factor in creating tuff was discussed. Plants which have an active role in genesis of tuff include Oocardum stratum, while others have a mostly passive role. Whether active or passive, plants have a formative role in creating tuff. 
Table 1 - Physical-chemical water characteristics of the Una River (Horvatinčic 2000).

\begin{tabular}{|l|c|c|c|c|c|r|}
\hline Locality & \multicolumn{1}{|c|}{$\begin{array}{l}\text { Measurement } \\
\text { date }\end{array}$} & ${ }^{\circ} \mathbf{C}$ & $\mathbf{p H}$ & $\begin{array}{c}\text { Bicarbonates } \\
{[\mathbf{m g} / \mathbf{I}]}\end{array}$ & $\begin{array}{c}\mathbf{C a} \\
{[\mathbf{m g} / \mathbf{I}]}\end{array}$ & $\begin{array}{c}\mathbf{M g} \\
{[\mathbf{m g} / \mathbf{l}]}\end{array}$ \\
\hline Una source & 21.06 .1984 & 9.3 & 7.53 & 212.3 & 65.6 & 8.3 \\
\hline Martin Brod & 21.06 .1984 & 10.5 & 8.20 & 235.5 & 77.6 & 10.4 \\
\hline Ripački slap & 15.05 .2000 & 11.9 & 8.24 & 250.1 & 77.0 & 8.8 \\
\hline Bihać & 15.05 .2000 & 12.5 & 8.23 & 262.3 & 75.5 & 9.0 \\
\hline
\end{tabular}

Ventilation of water is also of great importance for creating tuff. Greater ventilation, therefore water less loaded with suspended deposits and less production of anthropogenic waste, means greater production of tuff deposits.

Under the same conditions tuff does not appear in some rivers and almost everyone agrees that the cause for that is greater acidity of river water in which plants do not need to absorb carbon dioxide, so it will not come to sedimentation of tuff from calcium carbonate. On the basis of analyses of water sampling in the Una, its physical-chemical characteristics are presented in Table 1.

In order to determine the absolute age of tuff in the Una River, ${ }^{14} \mathrm{C}$ dating conducted at the Institute Ruđer Bošković, Zagreb, reveals that tuff in the upper flow originated before $2940 \pm 120$ years. In order to determine the age of old tuff deposits out of the Una's bed, ${ }^{230} \mathrm{Th}$ and ${ }^{234} \mathrm{U}$ datings were used, which estimate the age as between 90000 to 130000 years. The age of tuff in the river bed and the old one in the paleogeographic bed of the Una belong to warm Pleistocene interglacials. According to these data, older tuff, out of the range of river waters, had originated in the last warm interglacial Ris-Würm, while the genesis of tuff in the Una's bed has recent Holocene geological characteristics.

Growth of tuff in warm glacial periods is confirmed by the fact that tuff sedimentation in river water is much faster during the warm period of the year, especially in summer, compared to the colder period, and is slowest during winter. From these conclusions it follows that in globally warming last decade tuff should have formed intensively, but the latest monitoring does not confirm this on any profile of the Una River.

Light accumulative sedimentation in the Una can be explained by changes in general natural geographic conditions in the basin created by humans. Negative anthropogenic trends include the exploitation of forest resources, increased agricultural activity, ruralization and urbanization of the basin's area.

The physical chemical quality of the water is changed by these factors as is the coefficient of overflows of the catchment waters which then flow to the Una watercourse. In muddy and dirty waters with a changeable regime of water level and water flow, accumulation of tuff is decreased. That is the period in which river water erodes tuff, making it disappear. Designating the national park at the upper flow of the Una was done to protect the river, even though scientific debates on the genesis and evolution of tuff were not included in the professional and scientific arguments.

\section{Conclusion}

Recent conditions of tuff rivers in Bosnia and Herzegovina present a tendency for erosion. What is the reason for that? The answers must be looked for in the component and complex analyses of physical geography, geological, biological, chemical and other processes, bearing in mind that this break is not typical for the recent genesis of tuff in caves and holes.

Investigations in the terrain have revealed that tuff disintegration at the Una waterfalls exceeds its formation. The causes must be found, above all, in hydro-climatic fluctuations and the quality of waters that drain the anthropogenically changed catchment area. Hydro-climatic fluctuations have their natural rhythms, recognized on old tuff, and defined by layers which belong to intensive and continuing sedimentation and layers of breaks in tuff accumulation. The key for future tuff deposits in the Una must be looked for in the past genesis and development of tuff deposits.

Changes mentioned above must be recognized sufficiently by all who care for the preservation of Una National Park in order to bring the whole basin into a balanced condition. These are rhythmic and cyclical processes to which all natural phenomena succumb. This process is longer from the beginning of anthropogenic intervention. Humans can accelerate it. Because of that, detailed research programmes, which will offer prognostic answers on the future development of this potamological system, must precede any anthropogenic interventions in the Una basin.

\section{References}

Ballif, P. 1899. Wasserbauten in Bosnien und der Herzegovina. Wien.

Federal Ministry of Physical (Zoning) Planning (eds.) 2008. Study of environmental vulnerability of the Federation of Bosnia and Herzegovina. Sarajevo.

Gams, H. 1969. Pflanzen und Tiere Europas. Hamburg.

Horvatinčić, N. 2000. Šta je sedra i kako ju zaštititi. In: Naučna tribina, Sedra rijeke Une i Una bez. sedre: 1930. Bihać.

Kanaet, T. 1968. Sedra u nekim našim rijekama. SANU - Odjeljenje prirodno - matematickih nauka. Beograd.

Matoničkin, I. \& Z. Pavletić 1963. Sedrene naslage u rijeci Uni i njihova biološka uvjetovanost. Geografski glasnik 25: 43-56. Zagreb.

Pevalek, I. 1956. Slap Plive u Jajcu na samrti. Naše starine III: 269-273. Sarajevo.

Roglić, J. 1951. Unsko-koranska zaravan i Plitvička jezera, Geomorfološka promatranja. Geografski glasnik 13: 49-66. Zagreb. 
Spahić, M. 2000. Rijeka Una - potamološke karakteristike. In: Naučna tribina, Sedra rijeke Une i Una ber. sedre: 9-18. Bihać.

Srdoč, D., N. Horvatinčić, B. Obelić, I. Krajcar \& A. Sliepčević 1985. Procesi taloženja kalcita u krškim vodama s posebnim osvrtom na Plitvička jezera. Krš Jugoslavije 11 (4-6, JAZU): 101-204. Zagreb.

\section{Authors}

\section{Muriz Spahić}

Doctor of geographical sciences, full professor at the Faculty of Science, University of Sarajevo, Bosnia and Herzegovina; President of the Association of Geographers of Bosnia and Herzegovina, editor of the scientific journal Acta Geographica Bosnia et Herzegovinae; author of 75 scientific papers and six books from the scientific domain of physical geography and environmental protection.

\section{Aida Korjenic}

Master of geographical sciences, senior assistant at the Faculty of Science, University of Sarajevo, Bosnia and Herzegovina; author of various scientific papers from the scientific domain physical geography and landscape planning.

\section{Edin Hrelia}

Master of tourism and protected of environment, assistant at the Faculty of Science, University of Sarajevo, Bosnia and Herzegovina. His main research themes are nature-based / sustainable tourism and environmental protection. 